Review

\title{
Designing Hydrogel-Based Bone-On-Chips for Personalized Medicine
}

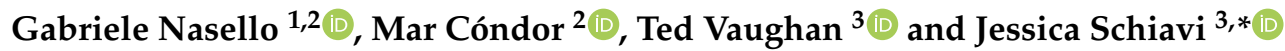 \\ 1 Multiscale in Mechanical and Biological Engineering (M2BE), University of Zaragoza, 50009 Zaragoza, Spain; \\ gnasello@unizar.es \\ 2 Biomechanics Section, Department of Mechanical Engineering, KU Leuven, 3000 Leuven, Belgium; \\ mar.condor@kuleuven.be \\ 3 Department of Biomedical Engineering, College of Engineering and Sciences, National University of Ireland, \\ H91 HX31 Galway, Ireland; ted.vaughan@nuigalway.ie \\ * Correspondence: jessica.schiavi@nuigalway.ie
}

Citation: Nasello, G.; Cóndor, M.; Vaughan, T.; Schiavi, J. Designing Hydrogel-Based Bone-On-Chips for Personalized Medicine. Appl. Sci. 2021, 11, 4495 https://doi.org/10.3390/ app11104495

Academic Editors: Marta Tunesi and Teresa Russo

Received: 31 March 2021

Accepted: 6 May 2021

Published: 14 May 2021

Publisher's Note: MDPI stays neutral with regard to jurisdictional claims in published maps and institutional affiliations.

Copyright: (c) 2021 by the authors. Licensee MDPI, Basel, Switzerland. This article is an open access article distributed under the terms and conditions of the Creative Commons Attribution (CC BY) license (https:/ / creativecommons.org/licenses/by/ $4.0 /)$.

\begin{abstract}
The recent development of bone-on-chips (BOCs) holds the main advantage of requiring a low quantity of cells and material, compared to traditional In Vitro models. By incorporating hydrogels within BOCs, the culture system moved to a three dimensional culture environment for cells which is more representative of bone tissue matrix and function. The fundamental components of hydrogel-based BOCs, namely the cellular sources, the hydrogel and the culture chamber, have been tuned to mimic the hematopoietic niche in the bone aspirate marrow, cancer bone metastasis and osteo/chondrogenic differentiation. In this review, we examine the entire process of developing hydrogel-based BOCs to model In Vitro a patient specific situation. First, we provide bone biological understanding for BOCs design and then how hydrogel structural and mechanical properties can be tuned to meet those requirements. This is followed by a review on hydrogel-based BOCs, developed in the last 10 years, in terms of culture chamber design, hydrogel and cell source used. Finally, we provide guidelines for the definition of personalized pathological and physiological bone microenvironments. This review covers the information on bone, hydrogel and BOC that are required to develop personalized therapies for bone disease, by recreating clinically relevant scenarii in miniaturized devices.
\end{abstract}

Keywords: bone-on-chip; bone microenvironment; bone hydrogels; tunable hydrogels; microfluidic bone treatments; bone models

\section{Introduction}

Musculoskeletal disorders and related bone diseases are one of the major causes of pain and disability as well as a social and economical burden for our society. Diseases such as osteoarthritis, bone fracture, osteoporosis, bone tumor and osteosarcopenia affect 1 of 2 adults in United States [1] and more than 100 million Europeans [2]. More specifically on bone alteration, the estimated incidence of bone fractures is 3 per 100 people per year in UK [3] and US [4]. Despite the intrinsic repair capacities of bone tissue, $5-10 \%$ of fractures are not self-healdling and described as non-unions and require expensive operative interventions [5]. Bone traumatic injuries cost \$56 billion every year in US alone [4], while fractures associated to osteoporosis cost $€ 37.5$ billion in the largest European countries [6]. In search of reducing the societal and economical burden of bone diseases, experimental models of bone tissue are continuously evolving to recapitulate specific mechanisms of bone physiology, pathology or to evaluate the effect of potential therapies. Two types of models are available, ex vivo models where bone tissue are cultured outside of the body [7] and in vitro models where cells are isolated and cultured in a $2 \mathrm{D}$ or $3 \mathrm{D}$ environment. In vitro experimental bone models are more easily available than living explants and facilitate the culture of human cells in a controlled environment outside of living organisms [8]. 
Moreover, a high number of parameters can be tested with one single batch. Yet, traditional $2 \mathrm{D}$ in vitro models are not suitable for long-term studies and may fail in recapitulating a clinically relevant environment due to the absence of all factors present in vivo [9], but their high output and outcome balance this weakness.

The lack of clinical relevance of 2D or the experimental challenge of large scale 3D in vitro models, which includes the high number of cells necessary and necrosis in the core of large scaffold, led to the development of the organ-on-chip field. The organ-onchip technologies have recently emerged from the synergy of microfabrication techniques and tissue engineering, aiming to replicate specific processes of organ functionality in sophisticated in vitro microenvironments and reduce the amount of cells required. While the use of organ-on-chips for drug screening is steadily increasing [10], the combination of microengineered systems with primary patient cells is inspiring the field of regenerative medicine [11] as well as personalized medicine, since they facilitate the use of cells isolated from individual patients [12]. Different organ-on-chips were recently developed to predict the variability between individuals associated to specific biological processes, such as the permeability of the blood-brain barrier [13], the inflammation of the human airways [14], the proliferation of multiple myeloma cells [15] and the drug-induced hematotoxicity [16].

Compared to other tissues, Bone-On-Chip (BOC) platforms have mostly emerged in recent years. The first literature review on the development and challenges of BOC systems has been recently published, showing the main technical solutions adopted to study bone cell function, bone regeneration and its interaction with multiple tissues [17]. Starting from a monolayer of mouse osteocyte-like cell line to study mechano-regulation under oscillatory fluid flow [18], BOCs moved to three dimensional (3D) culture systems that investigated the osteocytic network formation $[19,20]$ or the bone matrix mineralization process [21]. Indeed, 3D culture environments mimicking the extracellular matrix (ECM) provide representative systems of tissue function where hydrogels are an ideal candidate to reflect the matrix topography and properties. The focus of this specific review is to describe the entire process to design BOC and to provide an informed perspective of the type and characteristic of hydrogels and cellular environment required to reproduce a disease state. First, we describe fundamental aspects of bone physiology and pathology, thus defining the biological context and requirements for BOCs. Second, we present the main hydrogels used to mimic the extracellular environment and possible techniques to tune their structural and mechanical properties. Later, we discuss hydrogel-based BOC platforms, developed in the last 10 years, in terms of cell source, design of the culture chamber and hydrogel used. Finally, we provide guidelines on how a BOC should meet the biological requirements by tuning the hydrogel mechanical properties, while keeping a strong focus on the development of devices for personalized medicine.

\section{Bone Tissue Microenvironment and Pathologies}

Skeletal growth and mineral acquisition predominate over the first two decades of the life of an individual. Over the subsequent decades, the skeleton continues to remodel with a balance between bone formation and resorption, but more gradually due to aging factors, metabolic disorders or pathology the remodeling of bone is altered and results in a decreased resistance to stress (Figure 1). Bone cells modify the tissue mineral content, quality and composition of the matrix, architecture, and shape in response to growth, physical forces, and trauma over the life span [22]. Bone also adapts to transient needs, for example, pregnancy and lactation produce reversible changes in the mineral content of the skeleton and in the mechanosensation. Indeed osteocytes in fibulae from lactating mice have larger lacunae which induces stronger response to mechanical loading with a decrease of Sost expression and an increase of $\beta$ catenin compared to those from virgin mice [23]. 


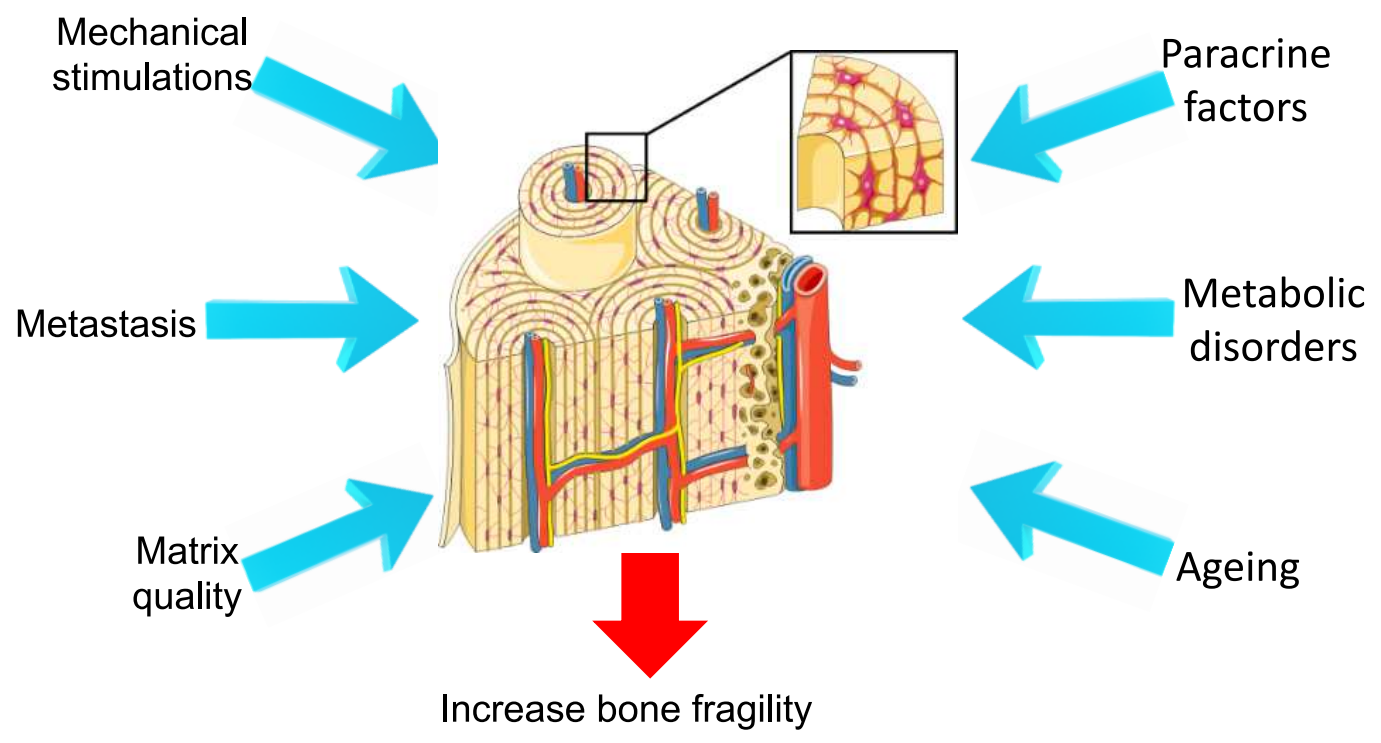

Figure 1. Parameters influencing bone remodeling. Human cortical bone is formed of Haversian canals surrounding by concentric lamellae and form osteons that are bond together by cement line. During ageing or due to several diseases there is an imbalance of the remodeling which changes the capacity of cells to respond to a treatment or support the osteointegration of an implant.

\subsection{Bone Microenvironment}

\subsubsection{Tissue}

Bone is a vascularised and innervated tissue that provides structural support for the body and transmits movements that are driven by muscle contractions. The tissue is the home for the aspirate marrow and the niche of stem cells capable of differentiating into bone cells, blood cells and in cells from the immune system. Long bones are composed of spongious bone (trabecular) and of cortical bone which forms a shell around the marrow. At the macroscale, the organisation of the matrix of long bone provides sufficient loadbearing capacity to accommodate the daily loads applied to the tissue. In humans, cortical bone is formed of osteons that are bound with cement line and are highly organized with a central Haversian canal that contains blood vessels and nerves and are surrounded by concentric lamellae of bone matrix. Within this matrix, dendritic cells, osteocytes are trapped in lacunae and form a highly interconnected network of canaliculi [24]. Those cells are considered the orchestrators of bone homeostasis and mechanosensation which permit the cells to response to mechanical stimulation. In fact, higher stress on bone increases bone formation while a significant decrease, as experienced during a space flight, reduces bone mass [25].

\subsubsection{Matrix}

The bone matrix is highly organised and surrounds osteocytes. Type I collagen composes $90 \%$ of the matrix and gives its toughness to the bone. Other non-collagenous proteins are present and essential to maintain the calcium within bone for the formation of hydroxyapatite (HA) crystals and contribute to the cohesion of the matrix. Indeed, osteocalcin, osteopontin and fibronectin are key proteins that facilitate the mineralization of the bone and increase its compliance. Bonds between collagen molecules are formed by enzymatic (lysyl oxidase) and non-enzymatic reactions such as oxidation. Those reactions can form unspecific bonds that accumulate during ageing in the bone matrix. Water composes about $10-20 \%$ of the volume of cortical bone and has a role in dissipating energy by reducing shear stress and interfaces within the tissue. This water can be free or bound to matrix component as glycosaminoglycans (GAGs) which correlates positively with bone toughness [26]. In the embryo, the matrix is produced by bone cells with the process of modelling and it is constantly renewed during the adult life through the remodeling. 


\subsubsection{Bone Cells}

Bone homeostasis is regulated by three type of cells: osteoblasts, osteocytes and osteoclasts. Their activities are regulated in response to variations in external loads and biochemical factors to adapt the tissue properties to those stimuli. Osteoblasts differentiate from the Mesenchymal Stem Cells (MSCs) present in the marrow of long bones. They produce the ECM and differentiate through the osteogenic pathway into osteocytes when they are surrounded by their own matrix. Osteoclasts are the bone resorbing cells. They are multinucleated cells formed from the fusion of differentiated cells from hematopoietic stem cells and remove the old or damaged bone matrix. Both of those cells are regulated by paracrine factors produced by osteocytes [24]. The factors released stimulate osteoblasts with osteoprogerin, and the osteoclasts with Sost and RANKL, to repair microdamage or renew the bone tissue in Bone Modelling Unit (BMU) [27]. These cells are embedded within the matrix and have a dendritic shape with mechanosensors present on the membrane extensions (i.e., integrins) which make them capable of sensing the shear stress induced by the movement of the extracellular liquid. The tri-dimensional shape of osteocytes is essential when considering in vitro culture as their culture in a 2D flat surface will dedifferentiate them into osteoblasts and thus change their response to stimuli [28]. When microdamage occurs, the disruption of dendrites induce the apoptosis of cells with an increase of caspase- 3 within the cytoplasm and an activation of RANKL expression by the nearby cells which active pathways to remodel the damaged area [29]. MSCs are multipotent cells present in the bone marrow and have a major role in bone remodeling. In addition they have therapeutic interest for tissue engineering as they have the capacity to differentiate into several cell phenotypes, and for cell therapy to treat the inflammation for example [30].

\subsubsection{Microenvironment of Cells Physico-Biochemical}

Within the bone, cells are in contact with a specific ECM that is highly organised and modifies the physical environment with a specific topography due to the different proteins of the matrix. This microenvironment changes with ageing or during some pathologies such as osteoporosis or type 2 diabetes. Indeed the high level of glucose creates aspecific non-enzymatic cross-links between proteins, called AGE (Advanced Glycation End point) which alter the mechanical properties of the tissues [31] and induces the apoptosis of osteoblastic cell lines [32]. Also, the biochemical environment of bone cells is modified in some specific conditions. Indeed the $\mathrm{pH}$ in $\mathrm{BMU}$ is affected by osteoclasts as they are activated with an acidic $\mathrm{pH}(\mathrm{pH} 7)$ which increases HA solubility and ultimately increase bone resorption [33].

\section{Mechanical}

The daily loads induce strain on the matrix that is transmitted to cells and act as one of the main activator of pathways implicated in bone metabolism [34]. As the fluid within the extracellular space is also subjected to the loading, it induces shear stress on the cell membrane and induces hydrostatic pressure as the system is confined. At the level of cells, fluid shear stresses induced within the network of osteocytes within the cortical bone has an average of $1 \mathrm{~Pa}$ around rat osteocytes in vivo [35] or within the marrow from 1.67 to 24.55 Pa during cyclic loading of porcine femurs [36]. Several studies have looked at the effect of shear stress on MSCs and bone cells on their mechanotransduction. Indeed in vitro application of oscillatory fluid flow to MSCs elicits a significant increase in collagen and mineral deposition when compared to static control demonstrating that mechanical stimuli within the marrow is sufficient to drive the osteogenesis [37]. Hydrostatic pressure is one important mechanical strain in bone during the different active phases of the day, with an estimation from 0 to $18 \mathrm{MPa}$ during a walk at $1 \mathrm{~Hz}$ within the lacunar-canalicular network [38]. In addition it has been shown that daily application of physiological hydrostatic pressure on MSC aggregates accelerates the formation of a mature mineralized 
bone tissue with the presence of bone specific protein (BSP2) [39] and the differentiation of osteoblast-like cells into osteocytes [40].

\subsection{Bone Pathologies}

\subsubsection{Non-Union Fracture}

Bone fracture or osteotomy are common and may prevent spontaneous healing without surgical repair and the use of scaffold or biomedical implants. The healing of such defects involved a series of four stages: formation of a hematoma, a soft callus, a hard callus and the remodeling of the matrix. The first 3 stages take place during the initial 3-4 weeks after which remodeling will occur for months or even years to regain a similar structure to the pre-fractured bone. During those phases the stiffness of the matrix goes from soft to high due to the formation a temporary template and then a mineralized matrix, which ultimately increase the energy of absorption to failure [41]. The composition of the callus varied from clotted blood with fibrin to fibrocartilage tissues, then first bone trabeculae are appearing in the callus until the union is formed.

\subsubsection{Osteoporosis}

Osteoporosis is a debilitating disease that is characterised by a decrease of the Bone Mineral Density that leads to a more brittle bone. Recently several studies have shown that shortly after the withdrawn of estrogen from the culture media of bone cells, osteoblasts release pro-osteoclast factors (RANKL) [42] and differentiate into a later stage of the osteogenic pathway [43]. Also estrogen deprivated osteocytes alters $\alpha_{v} \beta_{3}$ expression which results in downstream signalling in osteocytes during post-menopausal osteoporosis [44]. All together those results showed a hyperstimulation of bone cells during estrogen deficiency which can be counteract by the inhibition of the actin cytoskeleton with an inhibitor of ROCK [43,45]. It makes the stiffness of the matrix surrounding bone cells a potential major factor for driving bone homeostasis in post-menopausal osteoporosis. In in vivo models of postmenopausal osteoporosis it has also been shown as well that secondary mineralisation occured at a late stage which might make the bone less compliant and more brittle, and explain the fragility of bone [46]. In addition the variability of phenotype between individual shown a limitation in predicting overall the outcome of osteoporosis when the trabecula thickness is thinner before the diseases is installed [47].

\subsubsection{Type 2 Diabetes}

During Type 2 Diabetes Mellitus (T2DM) it is know that the prevalence of fracture increases in both males and females [48]. However, it is not fully understood how the bone is affected as several studies show that patients have DEXA scores with similar or higher bone mineral density. Some evidence are pointing out changes at the microscale level where the mineralization of cancellous bone is significantly more heterogeneous $(+26 \%)$ in patients presenting with T2DM compared to osteoarthritic controls with a significant increase of low mineral density bone volume [49]. In addition, it is know that bone mechanical properties are altered by a high glucose exposition which induces an increase of the formation of Advanced Glycation End produced (AGE) and the propensity of cancellous bone to fracture [50]. Although at the nanolevel, the increase of fracture could be explained by the low affinity of glycated osteocalcin to the hydroxyapatite crystal surface which decreases the capacity of osteocalcin to dissipate the energy and could make the bone more brittle [51]. In addition, the glycation of proteins not only affects bone quality but as well the blood vessels physiology and formation which limits the capacity for fracture healing, particularly for large defects [52] and alters the physiology of bone cells [53]. Indeed, ECM glycation alters their connection with cells via the integrins to the matrix which modify the physiology of cellular growth, proliferation, migration, cell signalling pathways, and bone remodelling. 


\subsubsection{Bone Metastasis}

Bone is one of the most common sites for breast cancer metastasis which has a direct impact of the survival of cancer patients. Indeed $22 \%$ of women with breast cancer developed bone metastasis with a median survival of 2.3 years [54]. Breast cancer cells that metastasize to bone often target the axial skeleton where trabecular bone is found in the bone marrow [55]. When metastatic breast cancer cells pass through blood vessels wall and engraft in trabecular bone, they face a unique mechanical environment that may affect their progression. The microenvironment is soft with rigid struts of bone matrix. These changes of stiffness and mechanical stimulation were simulated in vitro by Curtis et al on a breast cancer cell line, 4T1, laden in a gelatin scaffold and showed changes in the proliferation and protein expression (PTHrP and OPN) within soft materials with mechanical properties similar to bone marrow [56]. This showed evidence of mechanosensitivity of cancerous cells to their microenvironment.

\section{Hydrogels}

Hydrogels are three-dimensional cross-linked polymer networks produced by the simple reaction of one or more monomers that, due to their hydrophilic nature, can absorb large quantities of water. Hydrogels -widely used as models of the ECM- have received considerable attention in recent years for tissue engineering and regenerative medicine applications, as they can be designed with controllable responses and because of their specific properties such as swelling in aqueous medium, their sensitivity to $\mathrm{pH}$, temperature or other stimuli [57]. However, a throughout knowledge of the properties of hydrogels and of the structure-property relationships is required in order to select the most appropriate material for a specific application.

\subsection{Classification of Hydrogels}

Hydrogels can be classified according to several criteria such as the nature of their macromolecular structure, on the final form of the system, or on the nature of the crosslinks [58]. Based on the nature of their macromolecular structure, hydrogels can be classified as natural, synthetic or hybrid.

Natural polymeric hydrogels are gelsmade from polymers that have a natural origin such as collagen, fibrin, chitosan, hyaluronic acid or alginate, and have been successfully employed for tissue engineering applications due to their biocompatibility, biodegradability and non-toxicity [59]. However, their mechanical strength is poor and their composition may vary from batch to batch. On the other hand, synthetic hydrogels are synthesized using synthetic polymers such as methacrylated gelatin, pluronic, or polyethylene glycol (PEG). Synthetic hydrogels have gradually replaced over the last years natural ones as it is easier to control physical and chemical properties than for natural polymers (i.e., matrix elasticity, ligand density and porosity) [60]. However, normal cellular processes, such as morphology changes, migration and proliferation, are inhibited in synthetic hydrogels unless they are designed to degrade over time. In fact, non-degradable hydrogels present typically a pure elastic mechanical behavior, while reconstituted ECMs, such as collagen or fibrin, are viscoelastic and exhibit a partial stress relaxation when a constant stress is applied [61] (Figure 2A). This explain the great effort made in the last years to develop a new class of synthetic hydrogels capable to not only reproduce the molecular stiffness but also the strain-stiffening and the extent of bundling, such as the thermo-responsive biomimetic polyisocyanopeptide (PIC) hydrogels [62].

Simultaneously, the lack of adequate mechanical strength of most natural polymers, have made researchers to develop hybrid scaffolds by combining various hydrogels with other components to improve their resistance to stress. For this, nanomaterials, biological factors, and combinations of biopolymers (e.g., proteins and polysaccharide) are added to hydrogels to produce Interpenetrating Networks (IPNs) and Soft Network Composites (SNCs), often referred as composite or hybrid hydrogels [63]. 
A Mechanical properties

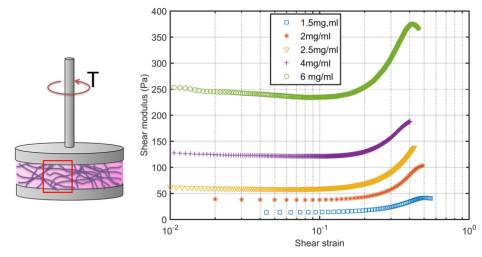

B Structural properties

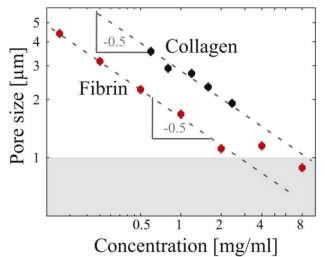

C Bone-On-Chip

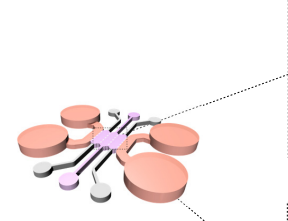

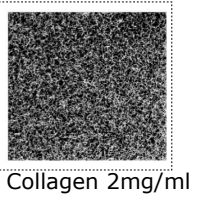

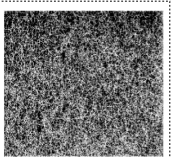

D Effect of cell encapsulation

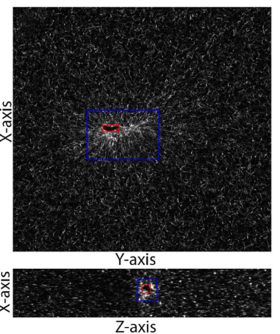

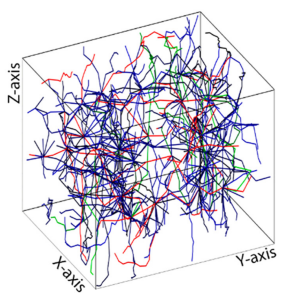

Near the cell

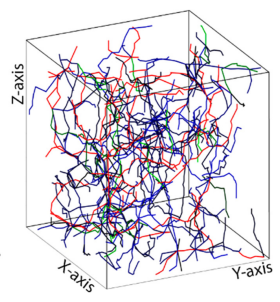

Far from the cell

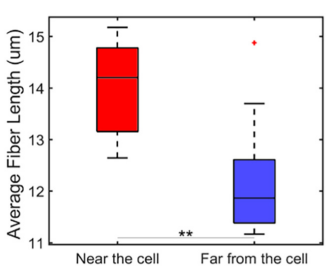

(A) Hydrogel mechanical properties as a function of network concentration. Scheme of a collagen hydrogel in the rheometer (left). Stress sweeps of five collagen hydrogels with different collagen concentration (right) after $24 \mathrm{~h}$ of polymerization (image from [64]). (B) Hydrogel structural properties as a function of network concentration. Concentration dependence of the average pore size of fibrin (red) and collagen (black) gels (image from [65]). (C) Reconstituted collagen-based hydrogels within a microfluidic chip. Maximum intensity projection in the $\mathrm{Z}$ direction of a $2 \mathrm{mg} / \mathrm{mL}$ and a $4 \mathrm{mg} / \mathrm{mL}$ 3D collagen type I network structure. Fiber images obtained with Nikon D-Eclipse C1 equipped with a 40X oil objective (image from [66]). (D) Effect of cell encapsulation within a collagen hydrogel. 3D reconstruction of collagen fibers in the vicinities of the cell or far from the cell (middle figures). Changes on average fiber length for the regions near the cell and far from the cell (right) (image from [66]). Images taken with permission from publishers.

\subsection{Synthesis of Hydrogels}

Hydrogels for tissue engineering applications must fulfill a number criteria, such as physical parameters (e.g., degradation and mechanics), mass transport parameters (diffusion requirements), biological performance parameters and biological interaction requirements for each specific application (e.g., cell adhesion) [67]. In addition, those specifically designed to encapsulate cells need to be non-toxic, gelled without damaging the cells, allow the diffusion of nutrients and support its handling during experiments. All these factors have to be considered in order to create a "custom-made" biomaterial and will determine the type of gelation utilized in hydrogel synthesis.

Hydrogels can be synthesized via various techniques, that include chemical crosslinking, physical cross-linking, polymerization grafting, and radiation cross-linking [68]. Attending the most common gelation methods utilized in hydrogel synthesis, it is normally distinguished between chemically or physically cross-linked hydrogels, based on the nature of the covalent bonds made within the matrix. Stable junctions or covalent bonds control the degree of swelling of the hydrogel based on their polymer-water relationship and the degree of reticulation in the matrix. On the other hand, physically cross-linked hydrogels result from ionic bonding, hydrogen bonding, physical interactions or molecular entanglements, which are reversible by application of force or other environmental changes [69,70]. Due to the absence of toxic cross-linking agents, physical cross-linking has gained greater importance over the last years compared with chemical cross-linking. Nevertheless, it is difficult to control the material properties of the hydrogel, such as gelation time, pore size, chemical functionalization, and degradation time due to lack of a cross-linking agent (Figure 2B,C) [71]. 


\subsection{Tuning Hydrogel Properties}

The properties of the cellular microenvironment are critical for cellular behavior and are dynamically regulated in living tissues. Cells sense the mechanical properties of the matrix through the linkage between membrane receptors and ECM proteins and, therefore, not only the matrix stiffness but also the type and concentration of anchoring proteins available for the cell to build up adhesion complexes and the way they are linked to the matrix or biomaterial, influence key cellular functions such as cell differentiation [72]. Furthermore, migrating cells are strongly affected by the steric hindrance constraints imposed by the surrounding ECM (e.g., pore size and porosity) [73] as well as other structural characteristics (e.g., fiber density and orientation) [66], that dictate the way in which they apply contractile forces, which in turn will modify the local mechanical properties of the surrounding matrix (Figure 2D). That is why the successful use of hydrogels in these applications relies on the ability to tune some properties, such as the degradation rate or the mechanical properties (e.g., cross-linking nature, density or dynamics) [74].

In order to increase the mechanical properties of hydrogels, often researchers tend to change the polymer or crosslinker concentration [75], thereby addressing the exploration of interesting cellular responses such as the effect of spatio-temporal gradients in mechanical properties on cell growth and migration, by using microfluidics techniques or photopolymerization [76]. However, changes in the crosslinker concentration modifies as well the porosity of the gel, which in turns affects the degradation dynamic and cell behavior (an increase of the cross-linker density causes a decreased degradation). Consequently, a tradeoff exists between the macroporosity $(10-400 \mu \mathrm{m})$ and the mechanical strength of the scaffold. As an alternative to improve hydrogel mechanical stability, covalent crosslinking of hydrogels has been used, but this is not an ultimate solution given the fact that chemical crosslinking is irreversible and may lead to the formation of toxic by-products $[77,78]$.

A common method to control the degradation rate of hydrogels is to incorporate peptides into the network that are targets for proteases. Several studies have demonstrated that changing either the concentration of these peptides or their amino acid target sequences (i.e., RGD) can be used to control the rate of gel degradation $[79,80]$. However, the hydrogel can result in the release of polymer fragments depending on the initial network connectivity or cleavage of chemical bonds, and little is known about how these degradation strategies, which is the loss of polymer content, may affect the spreading of cells, migration and proliferation.

\section{Hydrogel-Based Bone-On-Chips}

The development of organ-on-chips typically starts from a microfabrication technique, such as mask-based photolithography, etching precise microscale pattern into photosensitive materials, thus creating a mold [81]. Later, soft lithography replicates the master pattern in the microengineered device. For organ-on-chips applications, the soft elastomer poly(dimethylsiloxane) (PDMS) is the standard material used for the stamp, given its optical transparency, and biocompatibility. Moreover, PDMS can restore hydrophobicity after the stamp is bonded to a flat surface, which facilitates the filling of the culture chamber with hydrogel [82]. The final device consists of transparent polymeric microchannels where mechanical stimuli, such as laminar fluid flow, and biochemical gradients can be applied, while tissue-tissue interfaces can be replicated [83]. Any organ-on-chip requires one or multiple cell types and a microscale culture chamber. Hereafter, the culture chamber designs, the hydrogels and the cellular components used in BOCs are discussed.

\subsection{Culture Chamber Designs}

The complexity of culture chamber designs in BOCs is intrinsically related to the composition of the tissue. Indeed multi-cellular and multi-tissue interaction can be modelled within each device. In general, single channeldevices are preferred for cell migration studies, where cells can be tracked over time within the hydrogel while applying mechanical [84] or chemical stimuli [85-87]. Microposts between channels facilitate the identification of 
the region of interests while taking multiple images over time and support the hydrogel stability via surface tension $[87,88]$. Moreover, microposts separate culture chamber, thus confining cells and hydrogels in compartments where different culturing conditions can be applied [89].

The definition of compartments in organ-on-chips is one of the main advantage of microengineered technologies over traditional culture techniques. By means of computer aided design (CAD), it is possible to tune the geometry of each single channel and the way multiple channels communicate with each other [90]. An example of effective culture chamber design in $\mathrm{BOC}$ is the one proposed by Mei et al., who studied cancer cell extravasation in bone tissue by creating channels for osteocytes and a lumen. In the osteocyte channel, cells could be selectively stimulated with oscillatory fluid flow, while the lumen channel consisted of a cylindrical hydrogel structure coated with endothelial cells and seeded with breast cancer cells. Moreover, the distance between the osteocyte and the lumen channel was $300 \mu \mathrm{m}$, to recapitulate the physiological distance between osteocytes and effectors cells [91]. Similarly, a bone-marrow-on-chip was recently developed based on two channels separated by a porous membrane. The two channels consisted of a hematopoietic and a vascular compartment. The in vivo functionality of the vascular lumen was replicated by feeding the whole chip exclusively via perfusion through the vascular compartment that was covered with endothelial cells [16]. For the microfabrication details of organ-on-chip devices comprising multiple cell types embedded in hydrogels, we recommend reading the protocol developed by Shin et al. [82], Huh et al. [92] and Novak et al. [93].

Besides using channels as culture chambers, microengineered system can induce chemical gradients within the culture environment. In addition, microfluidic devices facilitate the application of independent fluid flows for different channels. Thus, a system of two serpentine channels perfused by different cell culture media induced an osteo/chondrogenic gradient within a single hydrogel. In this way, the same hydrogel-based environment induced a differentiation gradient for MSCs mimicking the interface between bone and cartilage [94].

\subsection{Hydrogels}

Given their remarkable biocompatibility and non-toxicity, natural hydrogels are often selected to imitate the native ECM in BOC systems (Table 1). The hydrogel choice depends on the specific environment to be modeled. For example, the formation of a fibrin matrix immediately after a bone injury makes fibrin gels a suitable model to study the healing of bone. By embedding osteoprogenitor cells, a fibrin gel can generate a healing bone-mimicking (BMi) microenvironment and induced the functional formation of a microvascular network [95]. Moreover, in the same project, the same microenvironment recreates a bone inflammatory model with the addition of a macrophage-like cell line (RAW264.7 cells).

In search of a model representing mature bone, fibrin was mixed with type I collagen which increased the hydrogel stiffness and its mechanical stability [96]. Due to its ubiquitous presence in the bone matrix, hydrogel-based BOC systems normally used type I collagen when culturing primary Human Osteoblasts (HOBs) (Table 1). The collagen mechanical properties varied between the different applications of the BOCs. In general, collagen concentration was higher when the system meant to induces osteogenic differentiation and mineralization [88,97], while it was lower when studying osteoblast migration $[84,85]$. Collagen-based hydrogels have a fibrous architecture whose interaction with the embedded cells alters both the hydrogel mechanical properties and the cellular activity within the BOC. It has been demonstrated that collagen fiber reorientation due to interstitial fluid flow increases osteoblasts migration [84]. Moreover, osteoblasts remodel the collagen hydrogel with proteolytic enzymes, the metalloproteinases, which in turn regulate cell migration through the matrix [85].

Hydrogels mechanical properties can be enhanced with composite systems. Besides mixing with fibrin, collagen I was also mixed with Matrigel prior to load within BOC 
devices (Table 1). Given that Matrigel is a gelatinous protein mixture, a composite hydrogel made of collagen I and Matrigel provides a variety of structural proteins and growth factors resembling the native ECM [63]. Although the incorporation of a bioactive inorganic phase in hydrogels has been widely investigated to boost hard tissue regeneration [98], bone formation was never assessed in hydrogel-based BOC while incorporating calcium phosphates or bioglasses. However, HA nanoparticles were incorporated in fibrin hydrogels and loaded into BOC systems and showed the inhibitory effect HA in cancer cell migration [99] and a stimulative effect on endothelial sprouting [100]. Instead of incorporating inorganic phases, recent hydrogel-based BOCs recreated mineralized microenvironments by combining a collagen I hydrogel with osteogenic factors [101] or by culturing osteo-differentiated MSCs that deposited newly mineralized matrix [97].

Table 1. Selection of recent studies using hydrogel-based bone-on-chips to model physiological or pathological bone microenvironments. Hydrogel concentrations are between brackets and expressed in $\mathrm{mg} / \mathrm{mL}$ or weight/volume $\%$. Abbreviations: $h B M$ human bone marrow derived, $M S C$ mesenchymal stem cell, $M D A-M B-231$ human mammary adenocarcinoma cell (high invasion capacity), HUVEC human umbilical vein endothelial cell, $M L O-Y 4$ murine osteocyte-like cell Line, $O D$ osteoblast-differentiated, BMSC bone marrow stromal cell, SUP-B15 acute lymphoblastic leukemia cell line, $H O B$ primary human osteoblasts, HS5 human bone marrow stromal cell line, DBP bone-inducing demineralized bone powder, $B M P$ bone morphogenetic protein, $H A$ hydroxyapatite, $S W 620$ human colon cancer, MKN74 human gastric cancer, $L F$ human lung fibroblast, $A D M S C$ adipose-derived mesenchymal stem cell, ECM extracellular matrix.

\begin{tabular}{|c|c|c|c|c|c|}
\hline Goal & Cells & Chamber & Hydrogel & Main findings & Ref \\
\hline \multirow[t]{5}{*}{$\begin{array}{l}\text { Cancer } \\
\text { metastasis }\end{array}$} & $\begin{array}{l}\text { MDA-MB-231 } \\
\text { hBM-MSC HUVEC }\end{array}$ & $\begin{array}{l}4 \text { independent gel } \\
\text { chambers }\end{array}$ & $\begin{array}{l}\text { Osteo-cell } \\
\text { conditioned } \\
\text { collagen (6.0) }\end{array}$ & $\begin{array}{l}\text { Extravasation of breast } \\
\text { cancer cells is influenced } \\
\text { by cell receptor CXCR2 }\end{array}$ & [97] \\
\hline & $\begin{array}{l}\text { MDA-MB-231 } \\
\text { MLO-Y4 HUVEC }\end{array}$ & $\begin{array}{l}\text { Lumen channel and } \\
\text { osteocyte channel }\end{array}$ & $\begin{array}{l}\text { Mix of collagen I } \\
\text { (5.5) and } \\
\text { Matrigel (2.5) }\end{array}$ & $\begin{array}{l}\text { Mechanically stimulated } \\
\text { osteocytes reduced breast } \\
\text { cancer cell migration }\end{array}$ & [91] \\
\hline & $\begin{array}{l}\text { hBM-MSC } \\
\text { OD-hBM-MSC } \\
\text { HUVEC } \\
\text { MDA-MB-231 }\end{array}$ & 1 gel channel & Fibrin (5.0) & $\begin{array}{l}\text { Bone-mimicking } \\
\text { microenvironment induced } \\
\text { the highest breast cancer } \\
\text { extravasation rates }\end{array}$ & [95] \\
\hline & $\begin{array}{l}\text { OD-MSC HUVEC } \\
\text { LF } \\
\text { MDA-MB-231 }\end{array}$ & $\begin{array}{l}1 \text { channel and } \\
\text { endothelial } \\
\text { monolayer on } \\
\text { lateral sides }\end{array}$ & $\begin{array}{l}\text { Mix of fibrin }(2.5) \\
\text { and collagen I } \\
(0.2)\end{array}$ & $\begin{array}{l}\text { 3D vascularized } \\
\text { spheroids-on-chip } \\
\text { enhances breast cancer cell } \\
\text { migration }\end{array}$ & [102] \\
\hline & $\begin{array}{l}\text { Cancer cell (SW620 } \\
\text { or MKN74) HUVEC } \\
\text { LF }\end{array}$ & $\begin{array}{l}\text { Separate channels } \\
\text { for tumor micro- } \\
\text { environment and } \\
\text { fibroblast } \\
\text { co-culture }\end{array}$ & $\begin{array}{l}\text { HA }(0.2-0.4 \%) / \\
\text { fibrin }(2.5) \\
\text { composite }\end{array}$ & $\begin{array}{l}\text { Inhibitory effect of HA in } \\
\text { colon cancer cell migration } \\
\text { and angiogenic sprout } \\
\text { formation }\end{array}$ & [99] \\
\hline $\begin{array}{l}\text { Osteochondro- } \\
\text { genesis }\end{array}$ & ADMSC & $\begin{array}{l}2 \text { lateral serpentine } \\
\text { channels and } 1 \\
\text { linear middle } \\
\text { channel }\end{array}$ & Agarose $(2.5 \%)$ & $\begin{array}{l}\text { Simultaneous osteogenic } \\
\text { and chondrogenic } \\
\text { differentiation of stem cells }\end{array}$ & [94] \\
\hline $\begin{array}{l}\text { Osteogenic } \\
\text { differentiation }\end{array}$ & НOB & $\begin{array}{l}3 \text { channels } \\
\text { separated by } \\
\text { trapezoidal posts }\end{array}$ & Collagen I (6.0) & $\begin{array}{l}\text { Recapitulation of } \\
\text { osteoblast maturation } \\
\text { toward osteocytes and } \\
\text { matrix mineralization }\end{array}$ & [88] \\
\hline
\end{tabular}


Table 1. Cont.

\begin{tabular}{|c|c|c|c|}
\hline Goal & Cells & Chamber & Hydrogel \\
\hline $\begin{array}{l}\text { Bone marrow } \\
\text { physiology }\end{array}$ & $\begin{array}{l}\text { Subcutaneous } \\
\text { implantation prior } \\
\text { to in vitro culture }\end{array}$ & $\begin{array}{l}\text { Cylindrical } \\
\text { chamber for the } \\
\text { explant and } \\
\text { perfusion channels }\end{array}$ & $\begin{array}{l}\text { Collagen I (3.0) } \\
\text { with DBP, BMP2, } \\
\text { BMP4 }\end{array}$ \\
\hline
\end{tabular}

$\begin{array}{ll}\text { Bone marrow } & \mathrm{CD}^{+} \text {cell BMSC } \\ \text { pathology } & \text { HUVEC }\end{array}$

Apical and basal Mix of fibrin (5.0) channels separated and collagen I by membrane

\begin{tabular}{ll} 
Main findings & Ref \\
\hline $\begin{array}{l}\text { Reconstitution of } \\
\text { hematopoietic niche } \\
\text { physiology and response to } \\
\text { radiation toxicity }\end{array}$ & \\
Prediction of clinically & \\
observed haemato- & \\
toxicities and & \\
representation of & \\
Shwachman-Diamond & \\
syndrome
\end{tabular}

Bone marrow

$\begin{array}{lll}\text { SUP-B15 BMSC } & 4 \text { channels } & \begin{array}{l}\text { Collagen I }(2.0 \\ \text { and 4.0) }\end{array}\end{array}$
microenvironment enhances leukemia cell survival during drug treatment

\begin{tabular}{|c|c|c|c|c|c|c|}
\hline & $\begin{array}{l}\text { leukemic c } \\
\text { HL60 or K } \\
\text { HUVEC H }\end{array}$ & $\begin{array}{l}11(\mathrm{U} 937, \\
62) \\
5\end{array}$ & $\begin{array}{l}\text { Gel channel, } \\
\text { leukemic channel } \\
\text { and endothelial } \\
\text { channel }\end{array}$ & $\begin{array}{l}\text { Collagen I ( } 2.5 \\
\text { and 5.0) }\end{array}$ & $\begin{array}{l}\text { Angiogenesis in bone } \\
\text { marrow promotes } \\
\text { leukemia cell proliferation } \\
\text { and survival }\end{array}$ & [104] \\
\hline $\begin{array}{l}\text { Vascularized } \\
\text { bone tissue }\end{array}$ & HUVEC & LF & $\begin{array}{l}4 \text { parallel channels } \\
\text { separated by } \\
\text { microposts }\end{array}$ & $\begin{array}{l}\text { HA }(0.05-0.5 \%) / \\
\text { fibrin }(-) \\
\text { composite }\end{array}$ & $\begin{array}{l}\text { HA enhances sprouting } \\
\text { speed and increased lumen } \\
\text { size, sprout length and } \\
\text { number }\end{array}$ & [100] \\
\hline \multirow[t]{3}{*}{ Cell migration } & НОВ & & 1 channel & Collagen I (4.0) & $\begin{array}{l}\text { Interstitial fluid flow alters } \\
\text { hydrogel microstructure } \\
\text { and cell migration }\end{array}$ & [84] \\
\hline & НOB & & 1 channel & Collagen I (4.0) & $\begin{array}{l}\text { The inhibition of ECM } \\
\text { degradation reduces cell } \\
\text { motility }\end{array}$ & [85] \\
\hline & hBM-MSC & & 1 channel & $\begin{array}{l}\text { Mix (1:1) of } \\
\text { collagen (2.0) } \\
\text { and Matrigel }\end{array}$ & $\begin{array}{l}\text { Dose-dependent } \\
\text { chemoattractant ability of } \\
\text { different chemokines }\end{array}$ & [87] \\
\hline
\end{tabular}

\subsection{Cell Interactions}

The selection and the number of different cell types to introduce in a BOC system includes, but it is not limited to, cells normally residing in the bone tissue, while the interaction with other tissues requires the use of different cell sources. The cellular component of the bone matrix is usually represented by osteoblasts or osteocyteswhile MSC and osteoclast precursors are included to study bone remodelling or to create a bone marrow niche. MSCs are routinely obtained from bone marrow or adipose tissue, and used as osteoprogenitor cells in organ-on-chip mimicked the mineralizing microenvironment $[95,102]$ or osteochondral bone formation [94]. On the other hand, MSCs were maintained in vitro to recapitulate the bone marrow microenvironment. Indeed, once seeded in a bone-marrowon-chip with $\mathrm{CD}_{4} 4^{+}$cells (hematopoietic stem cells), it has supported white and red blood cells differentiation over 4 weeks of culture while improving the maintenance of CD34 ${ }^{+}$ progenitors over traditional culture methods [16] (Figure 3A). A different approach from the traditional isolation and seeding of primary human cells has been proposed to recapitulate the physiology of bone marrow. Briefly, it consisted of a prior in vivo implantation of an hydrogel-based bone microenvironment. After 8 weeks, the hydrogel was populated by 
multiple hematopoietic cells and it was cultured in a microfluidic device after explantation to recapitulate a hematopoietic niche in vitro. Bone-marrow-on-chips and whole marrow from live mice showed comparable resistance to radiation, unlike stroma-supported cultures on a dish [101].
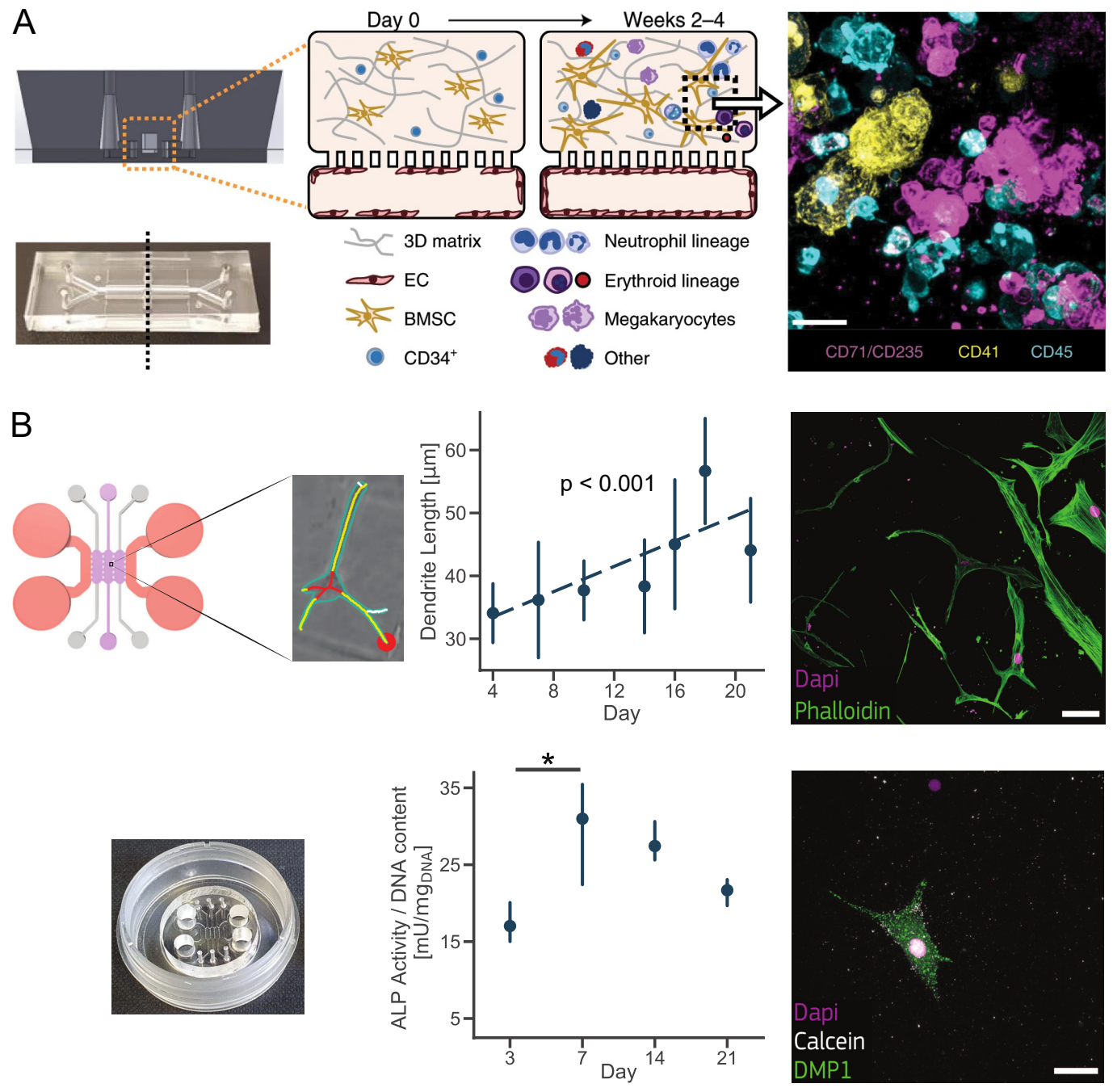

Figure 3. Inducing cell differentiation in hydrogel-based bone-on-chips. (A) A vascularized human bone marrow-on-chip was developed with optically clear poly(dimethylsiloxane) channels. In the top channel, hematopoietic stem cells $\left(\mathrm{CD} 34^{+}\right)$were seeded, while endothelial cells (EC) created a vascular lumen in the bottom channel. After 2 weeks of in vitro culture, hematopoietic stem cells differentiated in multiple blood cell types (magenta: erythroid lineage; yellow: megakaryocyte lineage; blue: neutrophil and other haematopoietic lineages). Scale bar, $20 \mu \mathrm{m}$. Image adapted from [16]. (B) Collagen-based bone-on-chip modeling primary human osteoblast differentiation into osteocytes. Cells increased primary protrusion length over time and exhibited dendritic morphology after 21 days of culture. Osteogenic differentiation was confirmed by an increasein alkaline phosphatase activity and synthesis of Dental Matrix Protein 1 (DMP1). * represents statistical significance $(p<0.05)$. Scale bar, $50 \mu \mathrm{m}$. Image adapted from [88]. Images were taken with permission from publishers.

In view of modeling the last stages of osteogenesis, $\mathrm{HOB}$ can be isolated from trabecular or cortical bone tissue. It has been showed that HOBs cultured in BOCs experience the specific changes in cellular morphology, protein secretion and proliferation observed in vivo [88] (Figure 3B). Due to the technical complexity of isolating primary human osteocytes from the mineralized bone, the murine osteocyte cell line MLO-Y4 was recently used in microfluidic systems to investigate the mechano-regulatory action of osteocytes [91]. Results showed, for the first time in a microfluidic device, that mechanically stimulated 
osteocytes reduced breast cancer extravasation [91]. The use of primary human osteocytes, or fully differentiated HOBs, in hydrogel-based BOCs will be critical for future patient-specific applications.

Besides including different cell types involved in the development, growth and remodeling of bones, a more realistic bone microenvironment requires modeling interactions between tissues made of those cells. For example, vascular tissue interacts with bone forming cells and affects both bone pathology and physiology. Indeed one BOC devicewas designed to deposit a layer of Human Umbilical Vein Endothelial Cells (HUVECs) on the external side of the hydrogelto recreate the interface between blood vessels and the bone matrix, and to simulate the extravasation process of cancer cells [97,104] (Figure 4). Indeed, the use of organ-on-chips facilitates the interaction between three to four different cells types to model the interaction between tumors, vascular and bone tissue. A few studies include fibroblasts when mimicking a tumor microenvironement since stromal cells are expected to nurture the tumor microenvironment and influence metastasis of the cancer $[99,102]$. Altogether those microengineered devices with endothelial cells contributed to identify the molecular pathways involved in the extravasation of breast cancer cells in bone [97], showed that the bone marrow microenvironment facilitates leukemia cell survival during drug treatment [103], and generated a vascularized network inside cell spheroids that permit to transport nutrients and cells to study metastasis [102].
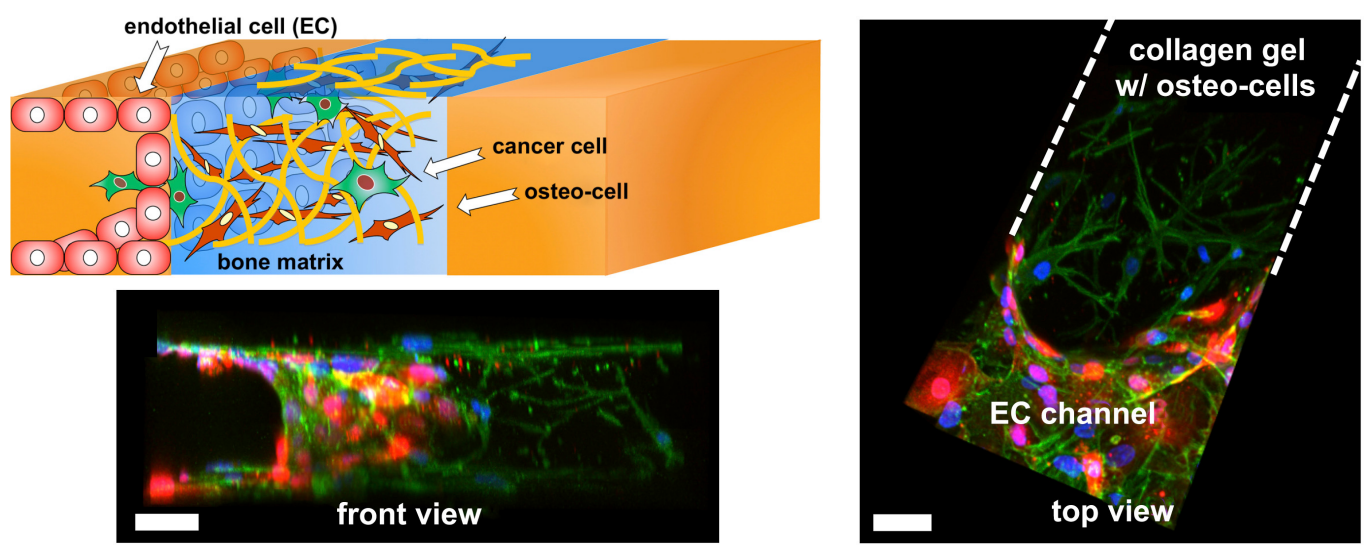

Figure 4. On-chip device modeling breast cancer metastasis in the bone tissue. Microfluidic device modeling breast cancer cell extravasation towards the bone tissue. Tri-culture system where osteodifferentiated mesenchymal stem cells created a bone-like environment by conditioning a collagen hydrogel. After seeding a monolayer of endothelial cells on the edge of the collagen hydrogel, breast cancer cells were introduced and their extravasation ability was assessed. Scale bar, $50 \mu \mathrm{m}$. Image adapted from [97]. Images were taken with permission from publishers.

\section{Towards Personalized Bone-On-Chips}

Bone not only provides structural support for the body to enable movement, but it also serves as a major stem cells (mesenchymal and hematopoietic) and metabolic storage site (i.e., for calcium). The diseases affecting bone have a wide spectrum of etiology but most of them induce frailty in patients with for example higher fracture risk. The complexity of the organ (several types of tissue, highly organised matrix) and of the symptoms make it difficult to predict the efficiency of treatments or the osteointegration of orthopedic implants. To recapitulate the diseases in vitro, the physical, mechanical and biochemical microenvironment that are key elements and specific to each pathology can be varied, such as a decreasing of the $\mathrm{pH}$ to study cancer metastasis [105] (Figure 5).

BOCs are an effective technology to build in vitro microenvironments resembling the specific pathological or physiological process under investigation. The essential components of hydrogel-based BOCs are the cellular sources, the hydrogel and the culture chamber which have been tuned to mimic the hematopoietic niche in the bone marrow $[16,101,103,104]$, cancer bone metastasis [91,95,97], or osteo/chondrogenic differentia- 
tion $[88,94]$. Hydrogels play an important role in engineering BOCs to mimic the specific characteristics of the microenvironment under investigation. First, hydrogels must be designed to encapsulate cells and gelate within the culture chamber without damaging the embedded cells. Collagen-based hydrogels are the most common choice in BOCs as this protein is the principal component of the mineralized bone matrix and the marrow matrix. Bone marrow niches are commonly associated to lower collagen concentrations, with lower mechanical properties, while an osteogenic microenvironment corresponded to higher collagen concentrations or by incorporating HA (Table 1). Besides collagen, fibrin hydrogels can accelerate bone healing [106], and model the early stage extracellular environment of bone diseases such as fracture healing and cancer tumor-fibrin matrix [107]. At the same time, the emergence of synthetic hydrogels have offered a wider control over the structural, chemical and mechanical properties. For example, thermo-responsive hydrogel could exponentially increase their stiffness after gelation, being an ideal model to investigate the cortical matrix or the pathological environment related to osteopetrosis.

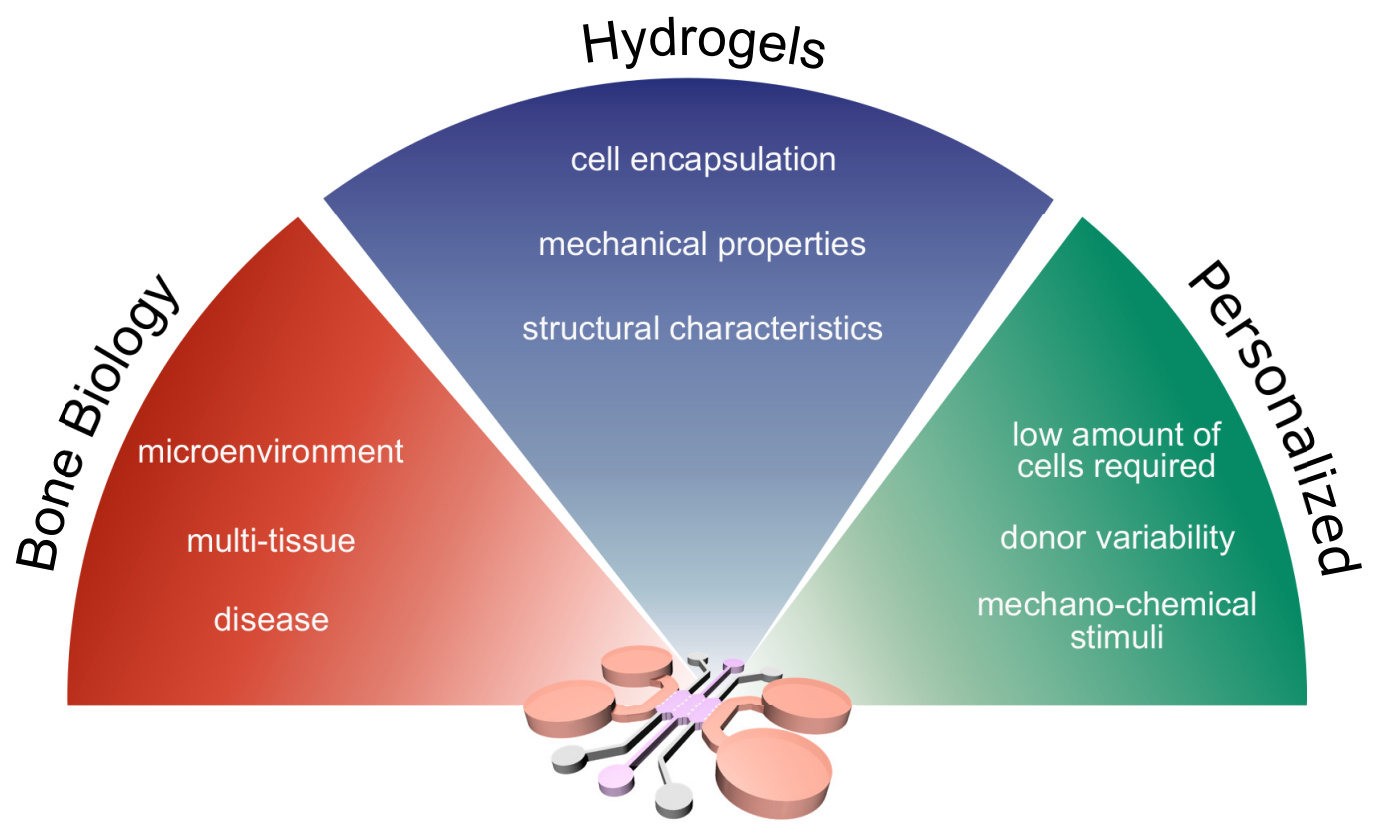

Figure 5. Modeling bone biology with personalized hydrogel-based bone-on-chips. Bone-on-chips aim at replicating specific functions of the bone tissue in sophisticated in vitro microenvironments. From a biological perspective, the variability associated with cell phenotype and bone diseases makes it difficult for traditional models to predict the efficacy of potential therapies. Each physiological or pathological bone process has a specific extracellular environment, which can be replicated by using hydrogels and tuning their biochemical composition, structural and mechanical properties. Therefore, hydrogel-based bone-on-chips offer personalized bone tissue models, where a proper combination of complex 3D microenvironments and primary human cells can answer questions on bone biology and test novel treatments.

Tuning and monitoring hydrogel structural properties over time can be used to model both physiological and pathological processes of the bone tissue. For example, the bone remodelling process has direct effects on matrix architecture and BOCs provide an innovative system that requires few ressources and where osteoblasts, osteoclasts and osteocytes can be simultaneously cultured in a 3D environment while monitoring the bone formation/resorption balance. However, the bone regeneration potential cannot only be reduced to variations in the osteogenic activity of osteoblast/osteocyte embedded in a 3D matrix. In order to build relevant models of bone regeneration, further research is needed to recapitulate the structural complexity of the bone tissue, as well as its interaction with any other tissue affecting the regeneration process [11]. As for pathological mechanisms, a precise control of the hydrogel architecture could replicate trabecula thickness of single individuals, 
which is considered a risk factor for postmenopausal bone loss [47]. Thus, BOCs could define patient-specific matrices and predict the outcome of osteoporosis based on the initial trabecula thickness. It is then clear that BOCs can help predicting the outcome of treatments by designing different bone characteristics with specific hydrogel composition. In addition, each sample can be patient-specific if a small bone explant is harvested and primary human cells extracted and seeded in a BOCs (Figure 5).

Patient-to-patient variability is a critical challenge for tissue engineering and personalized therapies where patient-specific organ-on-chips offer innovative systems to predict biological variability between individuals $[12,13]$. A BOC system has already compared the osteogenic activity of bone cells isolated from different patients [88]. Thus, future studies might determine how bone-related disorders alter the osteogenic activity of primary human bone cells by means of controlled experimentation with patient-specific BOCs. Furthermore, the organ-on-chip technology relies on the use of microfluidic systems to apply various mechanical stimuli on cells where the culture condition could be monitored with microscale and nanoscale biomedical sensors $[108,109]$. Indeed human tissues are characterized by different mechanotransduction signals, thus organ-on-chips offer alternative solutions to apply multiple mechanical and physical cues, such as shear and interstitial flow, cyclic stretching, stiffness gradient or geometric confinement [110]. In addition, as for the bone tissue, osteocyte regulatory role of both bone formation and resorption processes is directly related to strains and fluid shear stresses in the lacunocanalicular network. It is know that extracellular proteins, such as glycocalyx, bind cell receptors, such as integrins, and activate mechanotransduction pathways by stretching the cell membrane [111]. Therefore, BOC platforms could investigate the osteocyte mechanotransduction with a direct control on the 3D matrix where cells are embedded and on the interstitial fluid flow that replicates the in vivo mechanical stimuli.

For future studies, BOC devices will not only be key for a precise personalized medicine, but it will also provide a great tool to study in vitro bone mechanobiology by applying mechanical stimuli. Therefore, BOCs can have a role in pre-clinical evaluation and are the ideal candidate to predict the individual mechano-sensitivity in bone regeneration in a controlled microenvironment. By reproducing around bone cells pathological conditions with the association of mechanical stimuli and circulating levels of specific factors, such as estrogen [44], in microfluidic devices, future studies might be capable to predict the individual mechano-sensitivity and bone regenerative capacity in vitro in these specific microenvironments. In conclusion, this review aims at providing essential background and guidelines on the design of hydrogel-based BOC platforms to model bone tissue. It is clear that the rapid advances in the organ-on-chip technology will allow to answer further biological questions and to test therapies in vitro at a small scale and with limited resource (cells, materials). In the near future of personalized medicine and therapies for bone disease, those major tools will allow to assess for each individual biological response with patient-specific BOCs that recreate clinically relevant scenarii in miniaturized devices and that could predict the outcome of a treatment. Future development of BOCs and hydrogels will be required to tune specifically the three microenvironments around cells (biochemical, physical and mechanical) and to permit real-time assessment with live microscopic studies. However, more detailed knowledge on changes at the nanolevel in the matrix of bone for each diseases will be required to improve the composition of the hydrogels.

Author Contributions: Conceptualization, project administration, writing-original draft, reviewing and editing G.N. and J.S.; writing-original draft, M.C.; writing-review and editing, T.V.; Supervision J.S. All authors have read and agreed to the published version of the manuscript.

Funding: This research received no external funding. However authors were funded by the European Research Council Horizon 2020 research and innovation programmes, for Gabriele Nasello by the Marie Skłodowska-Curie grant agreement No 722535 (CuraBone project), for Jessica Schiavi by the ERC Starting Grant MULT2D held by Ted Vaughan (No 804108), and for Mar Cóndor was funded by the FWO fellowship 12ZR120N. 
Conflicts of Interest: The authors declare no conflict of interest.

\section{References}

1. United States Bone and Joint Initiative. The Burden of Musculoskeletal Diseases in the United States (BMUS), 3rd ed.; Rosemont, IL, USA, 2014; p. 711. Available online: http:/ / www.boneandjointburden.org (accessed on 1 March 2021).

2. Plannel, J.; Navarro, M. Challenges of bone repair. In Bone Repair Biomaterials; Elsevier: Amsterdam, The Netherlands, 2009; pp. 3-24. [CrossRef]

3. Donaldson, L.J.; Reckless, I.P.; Scholes, S.; Mindell, J.S.; Shelton, N.J. The epidemiology of fractures in England. J. Epidemiol. Community Health 2008, 62, 174-180. [CrossRef] [PubMed]

4. Buza, J. Bone healing in 2016. Clin. Cases Miner. Bone Metab. 2016. [CrossRef] [PubMed]

5. Einhorn, T.A. Enhancement of fracture-healing. J. Bone Jt. Surg. 1995, 77, 940-956. [CrossRef] [PubMed]

6. Borgström, F.; Karlsson, L.; Ortsäter, G.; Norton, N.; Halbout, P.; Cooper, C.; Lorentzon, M.; McCloskey, E.V.; Harvey, N.C.; Javaid, M.K.; et al. Fragility fractures in Europe: Burden, management and opportunities. Arch. Osteoporos. 2020, 15, 59. [CrossRef]

7. Cramer, E.E.A.; Ito, K.; Hofmann, S. Ex vivo Bone Models and Their Potential in Preclinical Evaluation. Curr. Osteoporos. Rep. 2021, 19, 75-87. [CrossRef]

8. Caddeo, S.; Boffito, M.; Sartori, S. Tissue Engineering Approaches in the Design of Healthy and Pathological In Vitro Tissue Models. Front. Bioeng. Biotechnol. 2017, 5. [CrossRef]

9. Boussommier-Calleja, A.; Li, R.; Chen, M.B.; Wong, S.C.; Kamm, R.D. Microfluidics: A New Tool for Modeling Cancer-Immune Interactions. Trends Cancer 2016, 2, 6-19. [CrossRef]

10. Zhang, B.; Korolj, A.; Lai, B.F.L.; Radisic, M. Advances in organ-on-a-chip engineering. Nat. Rev. Mater. 2018, 3, 257-278. [CrossRef]

11. Harink, B.; Le Gac, S.; Truckenmüller, R.; van Blitterswijk, C.; Habibovic, P. Regeneration-on-a-chip? The perspectives on use of microfluidics in regenerative medicine. Lab A Chip 2013, 13, 3512. [CrossRef]

12. van den Berg, A.; Mummery, C.L.; Passier, R.; van der Meer, A.D. Personalised organs-on-chips: Functional testing for precision medicine. Lab A Chip 2019, 19, 198-205. [CrossRef]

13. Vatine, G.D.; Barrile, R.; Workman, M.J.; Sances, S.; Barriga, B.K.; Rahnama, M.; Barthakur, S.; Kasendra, M.; Lucchesi, C.; Kerns, J.; et al. Human iPSC-Derived Blood-Brain Barrier Chips Enable Disease Modeling and Personalized Medicine Applications. Cell Stem Cell 2019, 24, 995-1005.e6. [CrossRef]

14. Benam, K.H.; Villenave, R.; Lucchesi, C.; Varone, A.; Hubeau, C.; Lee, H.H.; Alves, S.E.; Salmon, M.; Ferrante, T.C.; Weaver, J.C.; et al. Small airway-on-a-chip enables analysis of human lung inflammation and drug responses in vitro. Nat. Methods 2016, 13, 151-157. [CrossRef]

15. Zhang, W.; Lee, W.Y.; Siegel, D.S.; Tolias, P.; Zilberberg, J. Patient-Specific 3D Microfluidic Tissue Model for Multiple Myeloma. Tissue Eng. Part C Methods 2014, 20, 663-670. [CrossRef]

16. Chou, D.B.; Frismantas, V.; Milton, Y.; David, R.; Pop-Damkov, P.; Ferguson, D.; MacDonald, A.; Vargel Bölükbaşı, Ö.; Joyce, C.E.; Moreira Teixeira, L.S.; et al. On-chip recapitulation of clinical bone marrow toxicities and patient-specific pathophysiology. Nat. Biomed. Eng. 2020, 4, 394-406. [CrossRef]

17. Mansoorifar, A.; Gordon, R.; Bergan, R.C.; Bertassoni, L.E. Bone-on-a-Chip: Microfluidic Technologies and Microphysiologic Models of Bone Tissue. Adv. Funct. Mater. 2020, 2006796. [CrossRef]

18. You, L.; Temiyasathit, S.; Lee, P.; Kim, C.H.; Tummala, P.; Yao, W.; Kingery, W.; Malone, A.M.; Kwon, R.Y.; Jacobs, C.R. Osteocytes as mechanosensors in the inhibition of bone resorption due to mechanical loading. Bone 2008, 42, 172-179. [CrossRef]

19. Sun, Q.; Choudhary, S.; Mannion, C.; Kissin, Y.; Zilberberg, J.; Lee, W.Y. Ex vivo construction of human primary 3D-Networked osteocytes. Bone 2017, 105, 245-252. [CrossRef]

20. Leclerc, E.; David, B.; Griscom, L.; Lepioufle, B.; Fujii, T.; Layrolle, P.; Legallaisa, C. Study of osteoblastic cells in a microfluidic environment. Biomaterials 2006, 27, 586-595. [CrossRef]

21. Hao, S.; Ha, L.; Cheng, G.; Wan, Y.; Xia, Y.; Sosnoski, D.M.; Mastro, A.M.; Zheng, S.Y. A Spontaneous 3D Bone-On-a-Chip for Bone Metastasis Study of Breast Cancer Cells. Small 2018, 14, 1-10. [CrossRef]

22. Weaver, C.M.; Peacock, M. Skeletal Changes across the Life Span. In Basic and Applied Bone Biology; Elsevier: Amsterdam, The Netherlands, 2019; pp. 189-202. [CrossRef]

23. Hemmatian, H.; Jalali, R.; Semeins, C.M.; Hogervorst, J.M.A.; van Lenthe, G.H.; Klein-Nulend, J.; Bakker, A.D. Mechanical Loading Differentially Affects Osteocytes in Fibulae from Lactating Mice Compared to Osteocytes in Virgin Mice: Possible Role for Lacuna Size. Calcif. Tissue Int. 2018, 103, 675-685. [CrossRef]

24. Bonewald, L. Osteocytes: A proposed multifunctional bone cell. J. Musculoskelet. Neuronal Interact. 2002, 2, $239-241$.

25. Martin, R. Toward a unifying theory of bone remodeling. Bone 2000, 26, 1-6. [CrossRef]

26. Burr, D.B. Changes in bone matrix properties with aging. Bone 2019, 120, 85-93. [CrossRef]

27. Delaisse, J.M.; Andersen, T.L.; Kristensen, H.B.; Jensen, P.R.; Andreasen, C.M.; Søe, K. Re-thinking the bone remodeling cycle mechanism and the origin of bone loss. Bone 2020, 141, 115628. [CrossRef]

28. Sawa, N.; Fujimoto, H.; Sawa, Y.; Yamashita, J. Alternating Differentiation and Dedifferentiation between Mature Osteoblasts and Osteocytes. Sci. Rep. 2019, 9, 13842. [CrossRef] 
29. Kennedy, O.D.; Herman, B.C.; Laudier, D.M.; Majeska, R.J.; Sun, H.B.; Schaffler, M.B. Activation of resorption in fatigue-loaded bone involves both apoptosis and active pro-osteoclastogenic signaling by distinct osteocyte populations. Bone 2012, 50, 1115-1122. [CrossRef]

30. Laroye, C.; Lemarié, J.; Boufenzer, A.; Labroca, P.; Cunat, L.; Alauzet, C.; Groubatch, F.; Cailac, C.; Jolly, L.; Bensoussan, D.; et al. Clinical-grade mesenchymal stem cells derived from umbilical cord improve septic shock in pigs. Intensive Care Med. Exp. 2018, 6, 24. [CrossRef]

31. Saito, M.; Kida, Y.; Kato, S.; Marumo, K. Diabetes, Collagen, and Bone Quality. Curr. Osteoporos. Rep. 2014, 12, 181-188. [CrossRef]

32. Mercer, N.; Ahmed, H.; Etcheverry, S.B.; Vasta, G.R.; Cortizo, A.M. Regulation of advanced glycation end product (AGE) receptors and apoptosis by AGEs in osteoblast-like cells. Mol. Cell. Biochem. 2007, 306, 87-94. [CrossRef] [PubMed]

33. Arnett, T.R. Extracellular pH Regulates Bone Cell Function. J. Nutr. 2008, 138, 415S-418S. [CrossRef]

34. Verbruggen, S.W.; Vaughan, T.J.; McNamara, L.M. Strain amplification in bone mechanobiology: A computational investigation of the in vivo mechanics of osteocytes. J. R. Soc. Interface 2012, 9, 2735-2744. [CrossRef] [PubMed]

35. Verbruggen, S.W.; Vaughan, T.J.; McNamara, L.M. Fluid flow in the osteocyte mechanical environment: A fluid-structure interaction approach. Biomech. Model. Mechanobiol. 2014, 13, 85-97. [CrossRef] [PubMed]

36. Metzger, T.A.; Schwaner, S.A.; LaNeve, A.J.; Kreipke, T.C.; Niebur, G.L. Pressure and shear stress in trabecular bone marrow during whole bone loading. J. Biomech. 2015, 48, 3035-3043. [CrossRef] [PubMed]

37. Stavenschi, E.; Labour, M.N.; Hoey, D.A. Oscillatory fluid flow induces the osteogenic lineage commitment of mesenchymal stem cells: The effect of shear stress magnitude, frequency, and duration. J. Biomech. 2017, 55, 99-106. [CrossRef]

38. Zhang, D.; Weinbaum, S.; Cowin, S.C. On the calculation of bone pore water pressure due to mechanical loading. Int. J. Solids Struct. 1998, 35, 4981-4997. [CrossRef]

39. Freeman, F.E.; Schiavi, J.; Brennan, M.A.; Owens, P.; Layrolle, P.; McNamara, L.M. Mimicking the Biochemical and Mechanical Extracellular Environment of the Endochondral Ossification Process to Enhance the In Vitro Mineralization Potential of Human Mesenchymal Stem Cells. Tissue Eng. Part A 2017, 23, 1466-1478. [CrossRef]

40. Naqvi, S.M.; Panadero Pérez, J.A.; Kumar, V.; Verbruggen, A.S.K.; McNamara, L.M. A Novel 3D Osteoblast and Osteocyte Model Revealing Changes in Mineralization and Pro-osteoclastogenic Paracrine Signaling During Estrogen Deficiency. Front. Bioeng. Biotechnol. 2020, 8. [CrossRef]

41. Li, J.; Kacena, M.A.; Stocum, D.L. Fracture Healing. In Basic and Applied Bone Biology; Elsevier: Amsterdam, The Netherlands, 2019; pp. 235-253. [CrossRef]

42. Allison, H.; McNamara, L.M. Inhibition of osteoclastogenesis by mechanically stimulated osteoblasts is attenuated during estrogen deficiency. Am. J. Physiol.-Cell Physiol. 2019, 317, C969-C982. [CrossRef]

43. Simfia, I.; Schiavi, J.; McNamara, L.M. ROCK-II inhibition suppresses impaired mechanobiological responses in early estrogen deficient osteoblasts. Exp. Cell Res. 2020, 396, 112264. [CrossRef]

44. Geoghegan, I.P.; Hoey, D.A.; McNamara, L.M. Estrogen deficiency impairs integrin $\alpha \mathrm{v} \beta 3$-mediated mechanosensation by osteocytes and alters osteoclastogenic paracrine signalling. Sci. Rep. 2019, 9, 4654. [CrossRef]

45. Simfia, I.; Schiavi, J.; McNamara, L.M. Alterations in osteocyte mediated osteoclastogenesis during estrogen deficiency and under ROCK-II inhibition: An in vitro study using a novel postmenopausal multicellular niche model. Exp. Cell Res. 2020, $392,112005$. [CrossRef]

46. O'Sullivan, L.M.; Allison, H.; Parle, E.E.; Schiavi, J.; McNamara, L.M. Secondary alterations in bone mineralisation and trabecular thickening occur after long-term estrogen deficiency in ovariectomised rat tibiae, which do not coincide with initial rapid bone loss. Osteoporos. Int. 2020, 31, 587-599. [CrossRef]

47. Li, Y.; Tseng, W.J.; de Bakker, C.M.; Zhao, H.; Chung, R.; Liu, X.S. Peak trabecular bone microstructure predicts rate of estrogen-deficiency-induced bone loss in rats. Bone 2021, 145, 115862. [CrossRef]

48. Romero-Díaz, C.; Duarte-Montero, D.; Gutiérrez-Romero, S.A.; Mendivil, C.O. Diabetes and Bone Fragility. Diabetes Ther. 2021, 12, 71-86. [CrossRef]

49. Parle, E.; Tio, S.; Behre, A.; Carey, J.J.; Murphy, C.G.; O’Brien, T.F.; Curtin, W.A.; Kearns, S.R.; McCabe, J.P.; Coleman, C.M.; et al. Bone Mineral Is More Heterogeneously Distributed in the Femoral Heads of Osteoporotic and Diabetic Patients: A Pilot Study. JBMR Plus 2020, 4. [CrossRef]

50. Tang, S.; Zeenath, U.; Vashishth, D. Effects of non-enzymatic glycation on cancellous bone fragility. Bone 2007, 40, 1144-1151. [CrossRef]

51. Tavakol, M.; Vaughan, T.J. The structural role of osteocalcin in bone biomechanics and its alteration in Type-2 Diabetes. Sci. Rep. 2020, 10, 17321. [CrossRef]

52. Caliaperoumal, G.; Souyet, M.; Bensidhoum, M.; Petite, H.; Anagnostou, F. Type 2 diabetes impairs angiogenesis and osteogenesis in calvarial defects: MicroCT study in ZDF rats. Bone 2018, 112, 161-172. [CrossRef]

53. Bansode, S.B.; Gacche, R.N. Glycation-induced modification of tissue-specific ECM proteins: A pathophysiological mechanism in degenerative diseases. Biochim. Et Biophys. Acta (BBA) Gen. Subj. 2019, 1863, 129411. [CrossRef]

54. Harries, M.; Taylor, A.; Holmberg, L.; Agbaje, O.; Garmo, H.; Kabilan, S.; Purushotham, A. Incidence of bone metastases and survival after a diagnosis of bone metastases in breast cancer patients. Cancer Epidemiol. 2014, 38, 427-434. [CrossRef]

55. Coleman, R.E. Clinical Features of Metastatic Bone Disease and Risk of Skeletal Morbidity. Clin. Cancer Res. 2006, 12, 6243s-6249s. [CrossRef] [PubMed] 
56. Curtis, K.J.; Schiavi, J.; Mc Garrigle, M.J.; Kumar, V.; McNamara, L.M.; Niebur, G.L. Mechanical stimuli and matrix properties modulate cancer spheroid growth in three-dimensional gelatin culture. J. R. Soc. Interface 2020, 17, 20200568. [CrossRef]

57. Amin, S.; Rajabnezhad, S.; Kohli, K. Hydrogels as potential drug delivery systems. Sci. Res. Essays 2009, 4, 1175-1183.

58. Ahmed, E.M. Hydrogel: Preparation, characterization, and applications: A review. J. Adv. Res. 2015, 6, 105-121. [CrossRef]

59. Cóndor, M.; Steinwachs, J.; Mark, C.; García-Aznar, J.; Fabry, B. Traction Force Microscopy in 3-Dimensional Extracellular Matrix Networks. Curr. Protoc. Cell Biol. 2017, 75. [CrossRef]

60. Fattah, A.R.A.; Daza, B.; Rustandi, G.; Berrocal-Rubio, M.A.; Gorissen, B.; Poovathingal, S.; Davie, K.; Cao, X.; Rosenzweig, D.H.; Lei, Y.; et al. Actuation Enhances Patterning in Human Neural Tube Organoids. bioRxiv 2020, doi:10.1101/2020.09.22.308411. [CrossRef]

61. Chaudhuri, O.; Gu, L.; Klumpers, D.; Darnell, M.; Bencherif, S.A.; Weaver, J.C.; Huebsch, N.; Lee, H.P.; Lippens, E.; Duda, G.N.; et al. Hydrogels with tunable stress relaxation regulate stem cell fate and activity. Nat. Mater. 2016, 15, 326-334. [CrossRef]

62. Liu, K.; Mihaila, S.M.; Rowan, A.; Oosterwijk, E.; Kouwer, P.H.J. Synthetic Extracellular Matrices with Nonlinear Elasticity Regulate Cellular Organization. Biomacromolecules 2019, 20, 826-834. [CrossRef]

63. Zhao, Z.; Vizetto-Duarte, C.; Moay, Z.K.; Setyawati, M.I.; Rakshit, M.; Kathawala, M.H.; Ng, K.W. Composite Hydrogels in Three-Dimensional in vitro Models. Front. Bioeng. Biotechnol. 2020, 8. [CrossRef]

64. Valero, C.; Amaveda, H.; Mora, M.; García-Aznar, J.M. Combined experimental and computational characterization of crosslinked collagen-based hydrogels. PLoS ONE 2018, 13, e0195820. [CrossRef]

65. Lang, N.R.; Münster, S.; Metzner, C.; Krauss, P.; Schürmann, S.; Lange, J.; Aifantis, K.E.; Friedrich, O.; Fabry, B. Estimating the 3D Pore Size Distribution of Biopolymer Networks from Directionally Biased Data. Biophys. J. 2013, 105, 1967-1975. [CrossRef] [PubMed]

66. Olivares, V.; Cóndor, M.; Del Amo, C.; Asín, J.; Borau, C.; García-Aznar, J.M. Image-based Characterization of 3D Collagen Networks and the Effect of Embedded Cells. Microsc. Microanal. 2019, 25, 971-981. [CrossRef] [PubMed]

67. Chen, Q.Z.; Liang, S.L.; Wang, J.; Simon, G.P. Manipulation of mechanical compliance of elastomeric PGS by incorporation of halloysite nanotubes for soft tissue engineering applications. J. Mech. Behav. Biomed. Mater. 2011, 4, 1805-1818. [CrossRef] [PubMed]

68. Mahinroosta, M.; Jomeh Farsangi, Z.; Allahverdi, A.; Shakoori, Z. Hydrogels as intelligent materials: A brief review of synthesis, properties and applications. Mater. Today Chem. 2018, 8, 42-55. [CrossRef]

69. Gulrez, S.K.H.; Al-Assaf, S.; Phillips, G.O. Hydrogels: Methods of preparation, characterisation and applications. In Progress in Molecular and Environmental Bioengineering_From Analysis and Modeling to Technology Applications; IntechOpen: London, UK, 2011, pp. 117-150. [CrossRef]

70. Gyles, D.A.; Castro, L.D.; Silva, J.O.C.; Ribeiro-Costa, R.M. A review of the designs and prominent biomedical advances of natural and synthetic hydrogel formulations. Eur. Polym. J. 2017, 88, 373-392. [CrossRef]

71. Varghese, S.A.; Rangappa, S.M.; Siengchin, S.; Parameswaranpillai, J. Natural polymers and the hydrogels prepared from them. In Hydrogels Based on Natural Polymers; Elsevier: Amsterdam, The Netherlands, 2020; pp. 17-47. [CrossRef]

72. Geiger, B.; Yamada, K.M. Molecular Architecture and Function of Matrix Adhesions. Cold Spring Harb. Perspect. Biol. 2011, 3, a005033-a005033. [CrossRef]

73. Cóndor, M.; Mark, C.; Gerum, R.C.; Grummel, N.C.; Bauer, A.; García-Aznar, J.M.; Fabry, B. Breast Cancer Cells Adapt Contractile Forces to Overcome Steric Hindrance. Biophys. J. 2019, 116, 1305-1312. [CrossRef]

74. Lang, N.R.; Skodzek, K.; Hurst, S.; Mainka, A.; Steinwachs, J.; Schneider, J.; Aifantis, K.E.; Fabry, B. Biphasic response of cell invasion to matrix stiffness in three-dimensional biopolymer networks. Acta Biomater. 2015, 13, 61-67. [CrossRef]

75. Steinwachs, J.; Metzner, C.; Skodzek, K.; Lang, N.; Thievessen, I.; Mark, C.; Münster, S.; Aifantis, K.E.; Fabry, B. Three-dimensional force microscopy of cells in biopolymer networks. Nat. Methods 2016, 13, 171-176. [CrossRef]

76. Vincent, L.G.; Choi, Y.S.; Alonso-Latorre, B.; del Álamo, J.C.; Engler, A.J. Mesenchymal stem cell durotaxis depends on substrate stiffness gradient strength. Biotechnol. J. 2013, 8, 472-484. [CrossRef]

77. Vedadghavami, A.; Minooei, F.; Mohammadi, M.H.; Khetani, S.; Rezaei Kolahchi, A.; Mashayekhan, S.; Sanati-Nezhad, A. Manufacturing of hydrogel biomaterials with controlled mechanical properties for tissue engineering applications. Acta Biomater. 2017, 62, 42-63. [CrossRef]

78. Ghoorchian, A.; Simon, J.R.; Bharti, B.; Han, W.; Zhao, X.; Chilkoti, A.; López, G.P. Bioinspired Reversibly Cross-linked Hydrogels Comprising Polypeptide Micelles Exhibit Enhanced Mechanical Properties. Adv. Funct. Mater. 2015, 25, 3122-3130. [CrossRef]

79. Madl, C.M.; Katz, L.M.; Heilshorn, S.C. Tuning Bulk Hydrogel Degradation by Simultaneous Control of Proteolytic Cleavage Kinetics and Hydrogel Network Architecture. ACS Macro Lett. 2018, 7, 1302-1307. [CrossRef]

80. Trappmann, B.; Baker, B.M.; Polacheck, W.J.; Choi, C.K.; Burdick, J.A.; Chen, C.S. Matrix degradability controls multicellularity of 3D cell migration. Nat. Commun. 2017, 8, 371. [CrossRef]

81. Huh, D.; Hamilton, G.A.; Ingber, D.E. From 3D cell culture to organs-on-chips. Trends Cell Biol. 2011, 21, 745-754. [CrossRef]

82. Shin, Y.; Han, S.; Jeon, J.S.; Yamamoto, K.; Zervantonakis, I.K.; Sudo, R.; Kamm, R.D.; Chung, S. Microfluidic assay for simultaneous culture of multiple cell types on surfaces or within hydrogels. Nat. Protoc. 2012, 7, 1247-1259. [CrossRef]

83. Esch, E.W.; Bahinski, A.; Huh, D. Organs-on-chips at the frontiers of drug discovery. Nat. Rev. Drug Discov. 2015, 14, 248-260. [CrossRef] 
84. Del Amo, C.; Olivares, V.; Cóndor, M.; Blanco, A.; Santolaria, J.; Asín, J.; Borau, C.; García-Aznar, J.M. Matrix architecture plays a pivotal role in 3D osteoblast migration: The effect of interstitial fluid flow. J. Mech. Behav. Biomed. Mater. 2018, 83, 52-62. [CrossRef]

85. Movilla, N.; Borau, C.; Valero, C.; García-Aznar, J. Degradation of extracellular matrix regulates osteoblast migration: A microfluidic-based study. Bone 2018, 107, 10-17. [CrossRef]

86. Moreno-Arotzena, O.; Mendoza, G.; Cóndor, M.; Rüberg, T.; García-Aznar, J.M. Inducing chemotactic and haptotactic cues in microfluidic devices for three-dimensional in vitro assays. Biomicrofluidics 2014, 8, 064122. [CrossRef]

87. Yoon, D.; Kim, H.; Lee, E.; Park, M.H.; Chung, S.; Jeon, H.; Ahn, C.H.; Lee, K. Study on chemotaxis and chemokinesis of bone marrow-derived mesenchymal stem cells in hydrogel-based 3D microfluidic devices. Biomater. Res. 2016, 20, 25. [CrossRef] [PubMed]

88. Nasello, G.; Alamán-Díez, P.; Schiavi, J.; Pérez, M.Á.; McNamara, L.; García-Aznar, J.M. Primary Human Osteoblasts Cultured in a 3D Microenvironment Create a Unique Representative Model of Their Differentiation Into Osteocytes. Front. Bioeng. Biotechnol. 2020, 8. [CrossRef] [PubMed]

89. Moraes, C.; Mehta, G.; Lesher-Perez, S.C.; Takayama, S. Organs-On-a-Chip: A Focus on Compartmentalized Microdevices. Ann. Biomed. Eng. 2012, 40, 1211-1227. [CrossRef] [PubMed]

90. Cóndor, M.; Rüberg, T.; Borau, C.; Piles, J.; García-Aznar, J. A web-based application for automated quantification of chemical gradients induced in microfluidic devices. Comput. Biol. Med. 2018, 95, 118-128. [CrossRef]

91. Mei, X.; Middleton, K.; Shim, D.; Wan, Q.; Xu, L.; Ma, Y.H.V.; Devadas, D.; Walji, N.; Wang, L.; Young, E.W.K.; et al. Microfluidic platform for studying osteocyte mechanoregulation of breast cancer bone metastasis. Integr. Biol. 2019, 11, 119-129. [CrossRef]

92. Huh, D.; Kim, H.J.; Fraser, J.P.; Shea, D.E.; Khan, M.; Bahinski, A.; Hamilton, G.A.; Ingber, D.E. Microfabrication of human organs-on-chips. Nat. Protoc. 2013, 8, 2135-2157. [CrossRef]

93. Novak, R.; Didier, M.; Calamari, E.; Ng, C.F.; Choe, Y.; Clauson, S.L.; Nestor, B.A.; Puerta, J.; Fleming, R.; Firoozinezhad, S.J.; et al. Scalable Fabrication of Stretchable, Dual Channel, Microfluidic Organ Chips. J. Vis. Exp. 2018. [CrossRef]

94. Shi, X.; Zhou, J.; Zhao, Y.; Li, L.; Wu, H. Gradient-Regulated Hydrogel for Interface Tissue Engineering: Steering Simultaneous Osteo/Chondrogenesis of Stem Cells on a Chip. Adv. Healthc. Mater. 2013, 2, 846-853. [CrossRef]

95. Jeon, J.S.; Bersini, S.; Gilardi, M.; Dubini, G.; Charest, J.L.; Moretti, M.; Kamm, R.D. Human 3D vascularized organotypic microfluidic assays to study breast cancer cell extravasation. Proc. Natl. Acad. Sci. USA 2015, 112, 214-219. [CrossRef]

96. Rao, R.R.; Peterson, A.W.; Ceccarelli, J.; Putnam, A.J.; Stegemann, J.P. Matrix composition regulates three-dimensional network formation by endothelial cells and mesenchymal stem cells in collagen/fibrin materials. Angiogenesis 2012, 15, 253-264. [CrossRef]

97. Bersini, S.; Jeon, J.S.; Dubini, G.; Arrigoni, C.; Chung, S.; Charest, J.L.; Moretti, M.; Kamm, R.D. A microfluidic 3D in vitro model for specificity of breast cancer metastasis to bone. Biomaterials 2014, 35, 2454-2461. [CrossRef]

98. Gkioni, K.; Leeuwenburgh, S.C.; Douglas, T.E.; Mikos, A.G.; Jansen, J.A. Mineralization of Hydrogels for Bone Regeneration. Tissue Eng. Part B: Rev. 2010, 16, 577-585. [CrossRef]

99. Ahn, J.; Lim, J.; Jusoh, N.; Lee, J.; Park, T.E.; Kim, Y.; Kim, J.; Jeon, N.L. 3D Microfluidic Bone Tumor Microenvironment Comprised of Hydroxyapatite/Fibrin Composite. Front. Bioeng. Biotechnol. 2019, 7. [CrossRef]

100. Jusoh, N.; Oh, S.; Kim, S.; Kim, J.; Jeon, N.L. Microfluidic vascularized bone tissue model with hydroxyapatite-incorporated extracellular matrix. Lab A Chip 2015, 15, 3984-3988. [CrossRef]

101. Torisawa, Y.S.; Spina, C.S.; Mammoto, T.; Mammoto, A.; Weaver, J.C.; Tat, T.; Collins, J.J.; Ingber, D.E. Bone marrow-on-a-chip replicates hematopoietic niche physiology in vitro. Nat. Methods 2014, 11, 663-669. [CrossRef]

102. Sano, E.; Mori, C.; Nashimoto, Y.; Yokokawa, R.; Kotera, H.; Torisawa, Y.S. Engineering of vascularized 3D cell constructs to model cellular interactions through a vascular network. Biomicrofluidics 2018, 12, 042204. [CrossRef]

103. Bruce, A.; Evans, R.; Mezan, R.; Shi, L.; Moses, B.S.; Martin, K.H.; Gibson, L.F.; Yang, Y. Three-Dimensional Microfluidic Tri-Culture Model of the Bone Marrow Microenvironment for Study of Acute Lymphoblastic Leukemia. PLoS ONE 2015, 10, e0140506. [CrossRef]

104. Zheng, Y.; Sun, Y.; Yu, X.; Shao, Y.; Zhang, P.; Dai, G.; Fu, J. Angiogenesis in Liquid Tumors: An In Vitro Assay for Leukemic-CellInduced Bone Marrow Angiogenesis. Adv. Healthc. Mater. 2016, 5, 1014-1024. [CrossRef]

105. Webb, B.A.; Chimenti, M.; Jacobson, M.P.; Barber, D.L. Dysregulated pH: A perfect storm for cancer progression. Nat. Rev. Cancer 2011, 11, 671-677. [CrossRef]

106. Gholipour, H.; Meimandi-Parizi, A.; Oryan, A.; Bigham Sadegh, A. The effects of gelatin, fibrin-platelet glue and their combination on healing of the experimental critical bone defect in a rat model: radiological, histological, scanning ultrastructural and biomechanical evaluation. Cell Tissue Bank. 2018, 19, 341-356. [CrossRef]

107. SIMPSON-HAIDARIS, P.; RYBARCZYK, B. Tumors and Fibrinogen. Ann. N. Y. Acad. Sci. 2006, 936, 406-425. [CrossRef]

108. Nasiri, S.; Khosravani, M.R. Progress and challenges in fabrication of wearable sensors for health monitoring. Sens. Actuators A Phys. 2020, 312, 112105. [CrossRef]

109. Hannah, S.; Blair, E.; Corrigan, D.K. Developments in microscale and nanoscale sensors for biomedical sensing. Curr. Opin. Electrochem. 2020, 23, 7-15. [CrossRef] 
110. Polacheck, W.J.; Li, R.; Uzel, S.G.M.; Kamm, R.D. Microfluidic platforms for mechanobiology. Lab A Chip 2013, $13,2252$. [CrossRef] [PubMed]

111. Burra, S.; Nicolella, D.P.; Jiang, J.X. Dark horse in osteocyte biology: Glycocalyx around the dendrites is critical for osteocyte mechanosensing. Commun. Integr. Biol. 2011, 4, 48-50. [CrossRef] [PubMed] 